\title{
Francis Young
}

English Catholics and the Supernatural, 1553-1829. Catholic Christendom, 1300-1700.

Farnham, Surrey and Burlington, Vermont: Ashgate, 2013. Pp. xii + 308. Hb, \$134.95.

One of the most enduring legacies of the Protestant Reformation in Britain is the conflation of Catholicism with "credulity" and "superstition." By the late sixteenth century, the notion that popery was a species of magic and witchcraft was a polemical commonplace well on its way to becoming a component of popular opinion. Subtly infiltrating academic discourse, it lingers on in the widespread assumption that Catholics played at best a marginal role in the process that Max Weber famously called "the disenchantment of the world." Francis Young's new study is both a critical investigation of the origins of this nexus and a spirited challenge to the tradition of scholarly interpretation that has arisen from it. The term "supernatural" in his title is a "conscious anachronism" (4), used in its nineteenth-century sense, to describe the realm of ghosts, witchcraft, and demonic possession. Although there is now a substantial historiography on all three topics in the English context, no historian has yet considered Catholic attitudes towards these phenomena in any detail. Adopting a longue durée approach which extends from the reign of Mary I to the emancipation of Catholics in 1829, Young's book is a largely successful attempt to fill this glaring gap. Rooted in extensive research and utilizing neglected texts and manuscripts, it rightly eschews functionalist approaches to its subject and insists that we must address witchcraft and exorcism as "powerful realities in their own right [...] rather than ciphers for other forms of subversion" (23).

Perhaps the most important finding of Young's analysis of how the leaders of the proscribed church of Rome (priests, gentry patrons, and the literate laity) responded to spiritual and diabolical interventions in human affairs is the existence - and persistence - of a strain of moderate skepticism about the supernatural within Catholic ranks. He shows how early humanist caution converged with the secular clergy's suspicion of the enthusiasm for the miraculous that was the hallmark of the Jesuit mission, and later with the neoAristotelian metaphysics of the Blackloists Thomas White, Kenelm Digby, and John Serjeant in the 1640 s and 1650 s. He traces its transmutation in the context of the rise of Jansenism and through to the radical rejection of supernatural intervention that distinguished Cisalpine attitudes by contrast with those of the ultramontane party in the later eighteenth century. In rescuing these marginalized voices, Young not only highlights the importance of the intraconfessional conflicts that divided the English Catholic community, but also nuances prevailing narratives about the decline of magic. Inverting accepted stereotypes, he repeatedly presents witchcraft as primarily a 
Protestant obsession (133) and stresses that Georgian Catholics were less likely to be accused of "superstitious" belief in the miraculous than Methodists and other dissenters. The idea that they counterfeited demonic possession and faked the supernatural nicely reflects the strand of skeptical agnosticism about such phenomena within Catholic ranks that has been eclipsed and overlooked for too long. Throughout the period this coexisted with alternative tendencies: with the "mystical recusancy" (38) of Sir Thomas Tresham and with the interest in witchcraft displayed by figures like the Benedictine monk Gregory Greenwood, whose Three Discourses of Witches and Witchcraft, written in the 1720 s, are edited from the original manuscripts in appendix 2.

Another commendable feature of Young's book is its determination to situate English Catholicism in its wider European context and to assess the influence of the theological and philosophical trends that constitute the continental Counter Reformation and Enlightenment. But in asserting that these were ultimately less significant in shaping Catholic responses to the supernatural than their common participation in the English cultural context, he reinforces the older idea that Catholicism in this country had unique and distinctive features. Young's ambitious chronological coverage does not permit him to do justice to all aspects of his subject and the relationship between "folk" survivalism and self-conscious adherence to the church of Rome is something of an unresolved tension in his analysis. Nor does he fully integrate all the threads that comprise it or follow through their implications. It is a particular pity in this respect that the book lacks a proper conclusion. Nevertheless, English Catholics and the Supernatural engages two topics in a fruitful conversation and, as a result, is a very welcome addition to the scholarship.

\author{
Alexandra Walsham \\ University of Cambridge Trinity College \\ amw23@cam.ac.uk
}

